work of the employed workers in Germany have deteriorated to an almost inconceivable extent under the Nazi Government.

\section{Supply of Electric Torches}

THF supply of pocket torches for the coming winter months is already being discussed by wholesalers and manufacturers. According to the Electrical Times of August 15, the evidence as to shortage or abundance is conflicting. Manufacturers at present are said to be rationing supplies to the wholesalers rather severely. American torches are difficult to obtain owing to import licences being withheld. Belgian and Dutch torches have disappeared completely. Any bulk supplies received are got rid of very readily. The public grew so accustomed to using these handy little accessories last winter that they are now buying them quite briskly although the long summer daylight hours render them unnecessary. Many hope that the various restrictions will be relaxed with the approach of winter. If this happens, the machinery of home production has been increased so extensively that maintenance of a steady and adequate supply will become possible. Much depends upon the Governmert's attitude towards raw materials. This authority urges the public to hold off purchasing until the late autumn, for batteries are not things that can be held in store without rapid deterioration, especially if kept in damp places. Others hold a more optimistic view. They point to the great strides taken by manufacturers to increase production to such an extent that the disappearance of foreign-made torches will more than be made good before next winter sets in. Supply firms, it is reported, are confident that the rush demand of last winter will be less severe and that all wants will be steadily met although there will be a slight increase in price.

\section{Greenkeeping Matters and the Gall Midge of Grasses}

THE Board of Greenkeeping Research has adapted its research station at St. Ives, Bingley, Yorks., to war-time conditions. Some of its new activities have already been mentioned in these pages, and the first war-time number of the Board's Journal of Greenkeeping Research (6, No. 21, from the Director, price $3 s, 9 d$. per copy post paid) contains a number of short papers which deal further with the altered needs of the present time. The Station's director, Mr. R. B. Dawson, outlines the general war-time policy of linking golf grounds with food production so far as possible, and Mr. R. B. Ferro describes "War-time Turf Policy" from the point of view of minimal attention without permanent damage. There is a very useful survey of gall midge damage to grass seed by Mr. H. F. Barnes of Rothamsted Experimental Station. Many species, mostly of the genera Dasyneura and Contarinia, are shown to have specialized relations with a number of separate grass hosts. The damage done to seed plots must be very great, but seedsmen are now willing to pay more attention to their crops. Mr. Barnes considers the possibility of biological control through the selection of early or late maturing strains of the various host grasses to avoid the period of egg-laying. The present number of the Journal also contains notes and abstracts of a number of papers and matters of interest to those who have to deal with grassland.

\section{Swordfish Attacking Vessels}

SINCE the seventeenth century, authentic accounts are on record of the spearing of ships by the swordfish (Xiphias) and its relatives the spear- or marlinspike-fishes (Makaira) and the sail-fishes (Istiophorus). The stories of these attacks, their effects and their causes, with much incidental information, have been gathered together and discussed in a 100-page monograph, illustrated by seven plates and several text-figures, by Dr. E. W. Gudger (Mem. Roy. Asiatic Soc. Bengal, 12, 215-315 ; 1940). The attacks, which have occurred in all parts of tropical seas, are delivered with force, for not only have ships been shaken from stem to stern by the blow, but also the penetrations recorded include the piercing of the copper covering, a 4 -inch birch plank, and 6 inches of the timbers of the brig Tinker of New York, and the remarkable case of the South Seas whaler Fortune of Plymouth, Mass., the timbers of which beneath their copper sheath were penetrated through 18.5 inches of hard wood, 14.5 inches being of dense oak. The speed of the swordfishes is, however, great, and that together with the size of the fish, which may weigh 1,200 lb. (Zane Grey's marlin), and the fine lines of the sword itself, accounts for the power and effect of the blow. The author describes the fishes as timid rather than pugnacious, and concludes that the attacks are generally made either by fishes which have been wounded and are dashing about in pain and fright, or inadvertently when the fishes are, particularly in darkness, following and attacking a shoal of fishes upon which they are preying.

\section{High-Speed X-Ray Photography}

SHADow photographs taken with an exposure short enough to show a moving bullet while passing through a block of wood were shown and discussed at a meeting of the American Physical Society held on June 21. According to a Science Service report, the photographs were taken by using a very brief electrical surge of high voltage and amperage got by charging a condenser in several seconds, and then discharging it through the X-ray tube. For the short space of time necessary to take the photograph, the new tube will carry a current of about 2,000 amperes at 100,000 volts. In photographing rapidly moving objects, a fine tungsten wire connected in the timing circuit is broken by the moving object so that the energy stored in the condensers is released at the correct instant. Possible applications discussed were the use of the method to study internal strains in rapidly moving machine parts and in the bones of the body in vigorous action. The new X-ray tube and technique have been developed in the Westing. house Lamp Division by Dr. C. M. Slack and his associates. 